\title{
Causes of drop out from a physical exercise supervised program specific to older adults
}

\author{
Motivos de abandono de um programa de \\ exercício físico específico para idosos
}

\section{Motivos de abandono de un programa de ejercicio físico supervisado para las personas mayores}

\author{
Paulo Giusti Rossi ${ }^{[a]}$, Leticia Carnaz ${ }^{[b]}$, Wanderson Luis Bertollo ${ }^{[a]}$, \\ Anielle Cristhine de Medeiros Takahashi ${ }^{[\mathrm{a}]^{*}}$
}

[a] Universidade Federal de São Carlos (UFSCar), São Carlos, SP, Brazil

[b] Universidade Sagrado Coração (USC), Bauru, SP, Brazil

\begin{abstract}
\footnotetext{
*PGR: Doctoral student, e-mail: paulo.giusti.rossi@gmail.com LC: PhD, e-mail: lecarnaz@gmail.com WLB: BS, e-mail: bertollow@yahoo.com.br ACMT: PhD, e-mail: anielle@ufscar.br
}

Introduction: Physical exercise when performed regularly brings several health benefits, especially for older adults. However, there are barriers that induce these individuals to withdraw from exercise. Objective: This study investigated the causes of drop out from a supervised physical exercise program specific to older adults. Methods: A semi-structured questionnaire was applied by telephone contact, containing questions about their reasons for leaving the program. Demographic data were analyzed by relative and absolute frequencies, and the Chi-square test was used to verify the associations between the variables collected. A significance level of 5\% was considered. Results: Fifty-nine older adults were interviewed and the main 
reasons for drop out were lack of time (33.9\%), emergence or worsening of disease (28.8\%), and the need to care for family members with health problems (18.7\%). A high percentage of older adults $(62.7 \%)$ showed a worsening in health status after leaving the program, with changes in muscle strength $(80.0 \%)$, balance (76.7\%), and motor coordination (40.0\%). Conclusion: A professional intervention is suggested to enable organizational control of factors related to lack of time, as well as a logistical monitoring service for older adults and/or family members who fall ill, promoting the return to practice as soon as possible.

Keywords: Patient Dropouts. Patient Compliance. Aging. Exercise.

\section{Resumo}

Introdução: $O$ exercício físico praticado regularmente traz inúmeros benefícios à saúde, especialmente aos idosos. Porém, algumas barreiras fazem com que uma parcela destes idosos abandone esta prática. Objetivo: Este estudo investigou os motivos do abandono de um programa de exercício físico supervisionado e específico para a população idosa. Métodos: Foi aplicado um questionário semiestruturado, via contato telefônico, com questões a respeito dos motivos de abandono ao programa. $O$ contato foi realizado por um pesquisador sem vínculo com os idosos. Os dados demográficos foram analisados por frequências relativas e absolutas, usou-se o teste Qui-quadrado para verificar as associações entre as variáveis coletadas. Considerou-se nível de significância de 5\%. Resultados: Foram entrevistados 59 idosos e os principais motivos de abandono relatados pelos idosos foram: falta de tempo (33,9\%), surgimento ou agravo de doenças $(28,8 \%)$ e necessidade de cuidar de familiares com problemas de saúde (18,7\%). Grande parcela dos idosos (62,7\%) apontou piora do estado de saúde após o abandono do programa, com alteração da força muscular (80,0\%), equilíbrio (76,7\%) e coordenação motora (40,0\%). Conclusão: Sugere-se uma intervenção profissional para viabilizar o controle de fatores relacionados à falta de tempo, assim como uma logística de acompanhamento dos idosos e/ou familiares que adoecem, promovendo o retorno à prática da forma mais breve possível.

Palavras-chave: Pacientes Desistentes do Tratamento. Adesão do Paciente. Envelhecimento. Exercício.

\section{Resumen}

Introducción: El ejercicio físico practicado en forma regular trae innumerables beneficios para la salud, especialmente para los ancianos. No obstante, algunas barreras hacen que parte de los ancianos abandonen esta práctica. Objetivo: Este estudio investigó los motivos de abandono de un programa de ejercicio físico específico para la población envejecida. Métodos: Fue aplicado un cuestionario semiestructurado, vía contacto telefónico, con preguntas respecto de los motivos por el cual abandonaron el programa. Los datos demográficos fueron analizados por frecuencias relativas y absolutas, y la prueba Chi-cuadrado para verificar las asociaciones entre las variables recolectadas. Se consideró un nivel de significancia del 5\%. Resultados: Fueron entrevistados 59 ancianos, siendo los principales hallazgos: falta de tiempo (33,9\%), surgimiento o agudización de enfermedades (28,8\%) y la necesidad de cuidar algún familiar con problemas de salud (18,7\%). La mayor parte de los ancianos (62,7\%) apuntó empeoramiento del estado de salud después del abandono del programa, con alteración de la fuerza muscular (80,0\%), equilibrio $(76,7 \%)$ y coordinación motora $(40,0 \%)$. Conclusión: Se sugiere una intervención profesional para viabilizar el control de los factores relacionados a la falta de tiempo, así como una logística de acompañamiento de los ancianos y/o familiares que lo necesitan, promoviendo el retorno a la práctica de la forma más rápida posible.

Palabras clave: Pacientes Desistentes del Tratamiento. Adhesión del Paciente. Envejecimiento. Ejercicio. 


\section{Introduction}

The world population is in a process of demographic restructuring, characterized by a reduction in fertility rates, decrease in mortality, and consequent increase in life expectancy [1 - 3]. Considering the growing process of aging, there is also increasing concern for the older adult population to enjoy this period in the best possible way. Thus, exercise has an important role in maintaining the independence of this population [4 - 9].

Physical exercise has great potential to reduce the incidence and management of chronic diseases of older adults, besides improving physical conditioning and quality of life, it promotes an increase in the number of years that a person remains active and independent [4$7,10]$. The regularity of the practice and maintenance of adequate levels are indicated as ways to improve the general condition $[7,11$ - 17] and quality of life of older adults [18], as these factors act in the maintenance of health and positive self-esteem [19], bringing social, psychological, physical $[13,20,21]$, and cognitive $[17,22]$ benefits, as well as short- and long-term well-being [7].

According to research data from the Ministry of Health, between 2006 and 2016 there was a 9.6\% increase in the population over 65 years who adhered to physical exercises of mild or moderate intensity for at least 150 minutes per week or vigorous intensity exercises for at least 75 minutes per week [23, 24]. Therefore, it is possible to note the increase in demand for physical exercise practices, encouraged by the knowledge of the practical benefits and importance of maintaining independence [25]. However, after initiating physical exercise, many older adults end up not continuing the practice, which reflects in low adherence to the proposed programs $[7,26,27]$.

There are many reasons that induce older adults to abandon the practice of physical exercises, among them, their own health problems [7,25, 27, 28], death or family health problems [14, 28], feeling old or needing rest [29], the negative perception of the effect of physical exercise on the body, such as pain and tiredness $[7,27,28]$, lack of appropriateness of the exercise to the limitations and abilities of the older adults $[27,28]$, and lack of companionship to carry them out [25], in addition to simply not liking to practice exercises [27]. However, studies that address the theme of dropout from the practice of physical exercise are still scarce [7, 25 - 28] and the majority have restricted samples, which sometimes undermines their methodological quality.
It is important to investigate not only the factors that lead to dropout, but also the causes that lead older adults to abandon this practice in structured and specific programs for this population, which are usually carried out under the supervision of trained professionals. Understanding these factors is fundamental in order to seek solutions to reduce drop out numbers from long-term programs, and aid elderly individuals to achieve the benefits of regular physical exercise [30]. In this scenario, the objective of the present study was to investigate the reasons for dropout from a 10 -year supervised physical exercise program specific to the older adult population.

\section{Methods}

The ratio of older adults who dropped out of the program was obtained from the database of the Geriatric Revitalization Program (Revita), and telephone contact was made to apply a semi-structured questionnaire. Abandonment of the practice of exercise, the request to leave the program, and the number of consecutive absences not justified for a period of more than three months were considered.

The objectives of physical exercise for older adults are to provide an opportunity for social contact, sports, and academic living for this population, aiming to improve quality of life, where physical exercises are performed in groups and developed specifically for older adults. Revita began in 2005, is held on the premises of the São Carlos Educational Foundation (FESC) and is maintained with resources from the City Hall and an agreement with the Federal University of São Carlos (UFSCar). The program consists of three weekly classes with 50 minutes duration and quarterly physical assessments. The prescription of activities follows the recommendations of the American College of Sports Medicine for physical exercises for older adults, which include exercises for muscle strengthening, flexibility, motor coordination, balance, and aerobic conditioning [31]. All classes are elaborated and supervised by physical education professionals and physiotherapists trained to work with this population. Physical and health assessments are performed quarterly and address heart rate, blood pressure, weight, stature, bioimpedance exam, hand grip strength, trunk flexibility, sitting and standing for 30 seconds, waist and hip circumference, unipodal 
balance, the Timed Up and Go test, and six-minute walk test. Feedback of the results occurs on the same day, when the results of the evaluation performed are compared with previous results.

The older adults who dropped out of Revita were identified from the class attendance frequency database. The inclusion criteria of the present study were individuals aged over 60 years who abandoned Revita in the period from 2005 to 2011. Exclusion criteria were absence of telephone number for contact, missing or new owner phone numbers, absence of contact after the fifth contact attempt on alternate days, refusal to participate in the study, failure to answer any of the questions asked, or the elderly individual was deceased. The telephone contact was carried out by an external evaluator who was not connected to the program. Through the telephone contact, questions were asked regarding the reasons why the elderly individual left the program; the current self-perception of their physical state; self-perception of social interaction; occurrence of continuity in the performance of some other physical exercise; and also issues related to self-awareness of practice.

The present study was carried out in the Department of Physical Therapy of UFSCar, under the approval of the Ethics and Research Committee on Human Beings of UFSCar number 36075/2012.

\section{Statistical Analysis}

The demographic data of the individuals included in the study, as well as the nominal variables collected through the questionnaire, were analyzed by means of relative and absolute frequencies, mean and standard deviation. Pearson's chi-square test $(\chi 2)$ with a significance level of $5 \%$ was applied to verify the association between the variables participation time in the program (less than or equal to 12 months/greater than 12 months), state of general health (improvement or maintenance of health status/worsening of health status), self-perception of physical alteration after abandonment of the program, and the occurrence of continuity of some physical exercise after leaving the program. We also analyzed the association between general health status (improvement or maintenance of health status/worsening of health status) and perception of physical alterations after abandonment of the program. For the statistical analysis, SPSS software, version 11.5 was used.

\section{Results}

Two hundred forty-seven older adults who left Revita between 2005 and 2011 were contacted through telephone calls. Figure 1 shows the flowchart with the numbers of individuals identified, contacted, and included in the study.

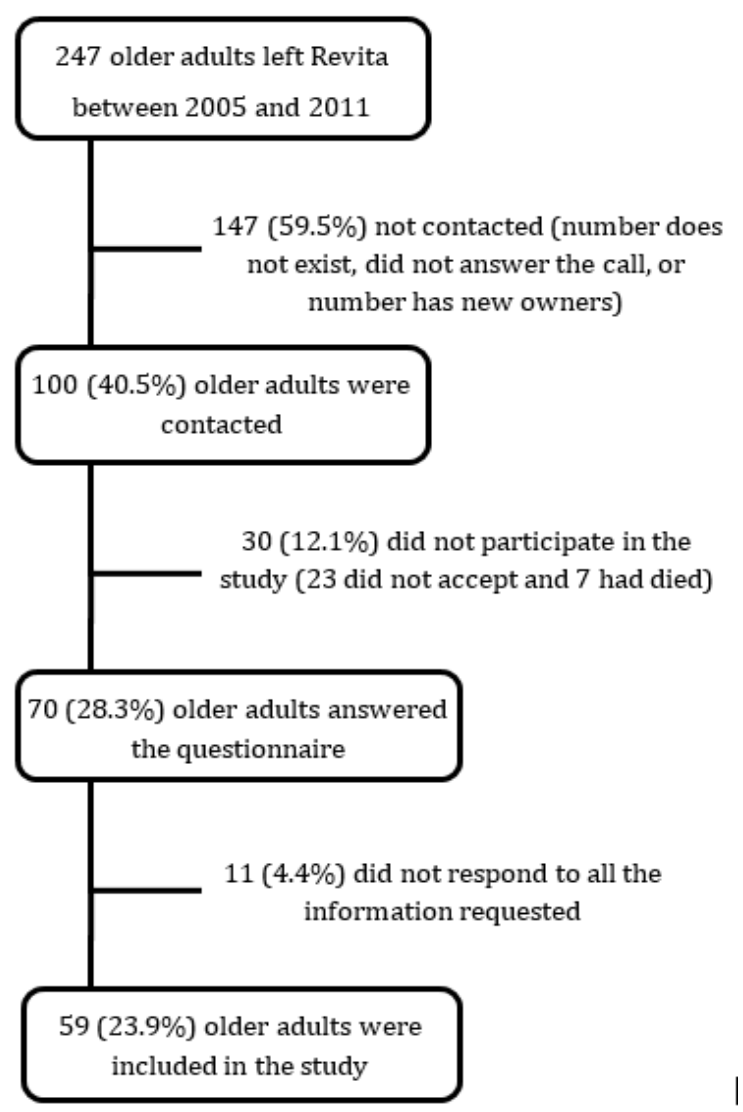

Figure 1 - Flowchart with the steps of the study: identification of older adults who dropped out, telephone contact, and application of the structured questionnaire.

The fifty-nine older adults included in the study attended the program for approximately 1.5 years (18.3 \pm 13.9 months), and on average they had ceased participation in the activities for 5 years $(60.8 \pm 17.7$ months). The reasons for abandoning Revita are presented in Figure 2. Lack of time, emergence or aggravation of diseases, and the need to care for family members with health problems were the main reasons reported by the individuals interviewed. Reports of monotony of proposed activities and lack of pleasure were less frequent, indicating that the reasons for abandonment may be related to everyday organizational issues. 


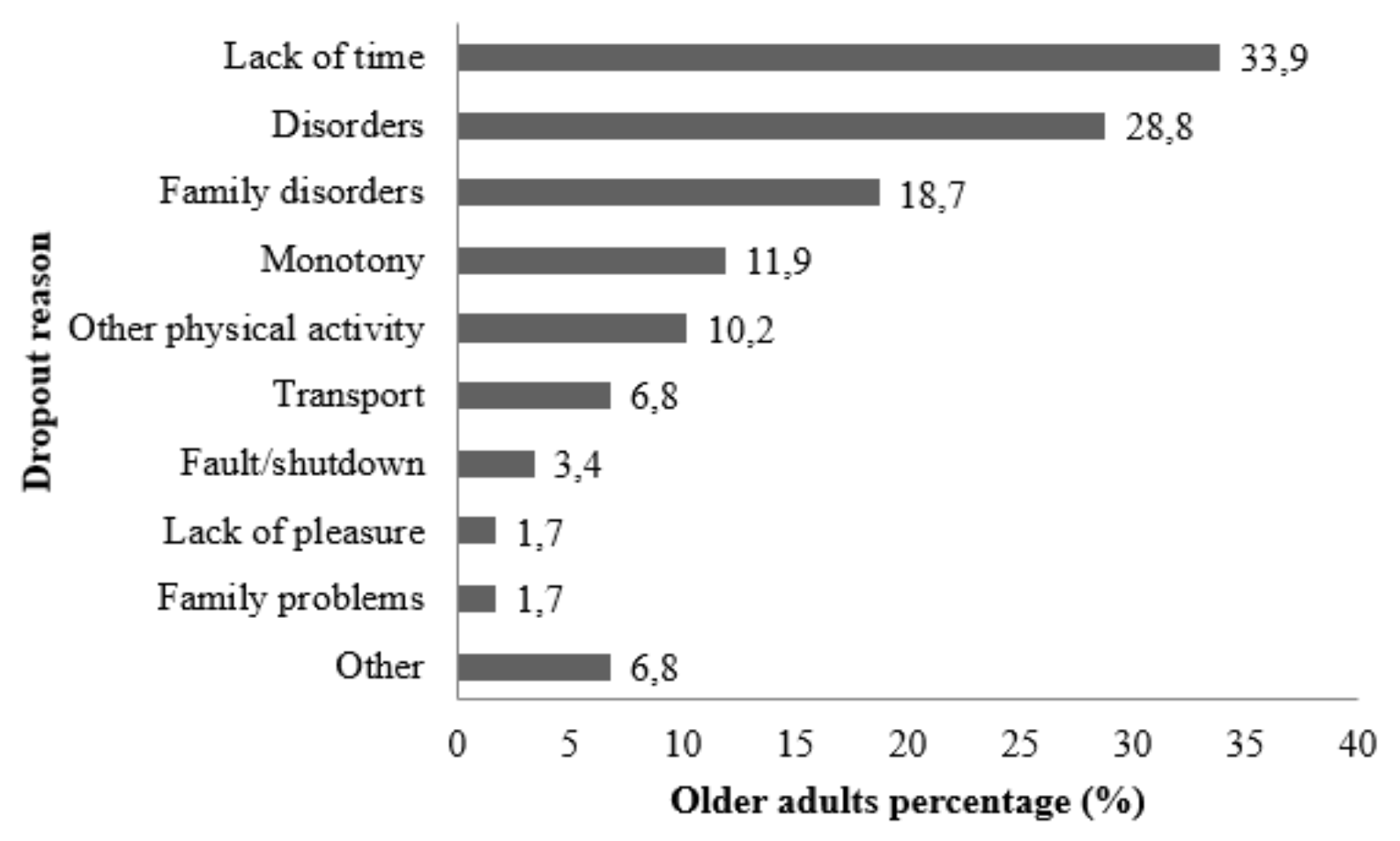

Figure 2 - Reasons for withdrawal from the practice of specific physical exercises for older adults.

Table 1 shows the results of the health condition, physical alterations, and maintenance of physical exercise practice by older adults after abandoning the Revita program. Regarding health conditions, the majority of the former program participants (62.7\%) reported worsening of general health. The older adults also described physical changes (50.9\%) as a consequence of the abandonment of physical exercises; the reduction in muscular strength, worsening of balance, and reduction in flexibility being the most frequently reported. The $\chi 2$ test showed an association between worsening of general health status and the presence of physical changes described by the older adults $(\mathrm{n}=59, \mathrm{gl}=1, \mathrm{p}=0.01)$.
A significant proportion of the older adults (69.5\%) continued to exercise after leaving the program. These data were associated with the length of stay in the program, so that individuals who participated for more than one year continued to practice exercises after their withdrawal from the program $(n=59, g l=1, p=0.004)$. In general, the activities after abandonment were performed 3 to 4 times a week (65.8\%), in agroup (61.0\%), and with guidance from a health professional (80.5\%). Despite this, no association was identified between maintenance of exercise practice and improvement or maintenance of general health status ( $\mathrm{n}=59, \mathrm{gl}=1, \mathrm{p}=0.182$ ). There was also no association between maintenance of physical exercise and prevention of physical changes $(n=59, g l=1, p=0.296)$. 
Table 1 - Characteristics of health condition, physical changes, and the practice of physical exercises after abandoning the Geriatric Revitalization Program

\begin{tabular}{|c|c|c|}
\hline \multicolumn{2}{|l|}{ Characteristic } & Total $(n=59)$ \\
\hline \multicolumn{3}{|c|}{ Health condition after leaving the program } \\
\hline \multicolumn{2}{|r|}{ Improved } & $3(5.1 \%)$ \\
\hline \multicolumn{2}{|r|}{ Stayed the same } & $19(32.2 \%)$ \\
\hline \multicolumn{2}{|r|}{ Worsened } & $37(62.7 \%)$ \\
\hline \multicolumn{3}{|c|}{ Physical change after leaving of the Program } \\
\hline \multicolumn{2}{|r|}{ No } & $29(49.1 \%)$ \\
\hline \multicolumn{2}{|r|}{ Yes } & $30(50.9 \%)$ \\
\hline \multicolumn{3}{|c|}{ If yes, which? } \\
\hline & Muscle strength & $24(80.0 \%)$ \\
\hline & Balance & $23(76.7 \%)$ \\
\hline & Motor coordination & $12(40.0 \%)$ \\
\hline & Flexibility & $20(66.7 \%)$ \\
\hline & Difficulty in ADL & $2(6.7 \%)$ \\
\hline \multicolumn{3}{|c|}{ Practice of physical exercises after leaving the Program } \\
\hline \multicolumn{2}{|r|}{ No } & $18(30.5 \%)$ \\
\hline \multicolumn{2}{|r|}{ Yes } & $41(69.5 \%)$ \\
\hline \multicolumn{3}{|c|}{ If no, plans to return to physical exercise } \\
\hline \multicolumn{3}{|r|}{$4(22.2 \%)$} \\
\hline \multicolumn{3}{|r|}{$14(77.8 \%)$} \\
\hline \multicolumn{3}{|c|}{ If no, what would it take to get back to physical exercise } \\
\hline & Time & $2(11.1 \%)$ \\
\hline & Companionship & $5(27.8 \%)$ \\
\hline & Income & $0(0.0 \%)$ \\
\hline & Disposition & $3(16.7 \%)$ \\
\hline & Others & 7 (38.9\%) \\
\hline
\end{tabular}

Note: Percentages were based on the number of respondents for each question; ADL: activities of daily living. Source: survey data.

Among the older adults who gave up and did not continue exercise, $77.8 \%$ intended to return to practice. In these cases, among the justifications for non-achievement, the lack of time, and absence of companionship and disposition were the main obstacles pointed out for not resuming a routine of physical exercise.

In general, after leaving Revita, the older adults missed the social aspects the most, such as lack of friends (62.7\%) and attention received by teachers (57.6\%) (Figure 3). 


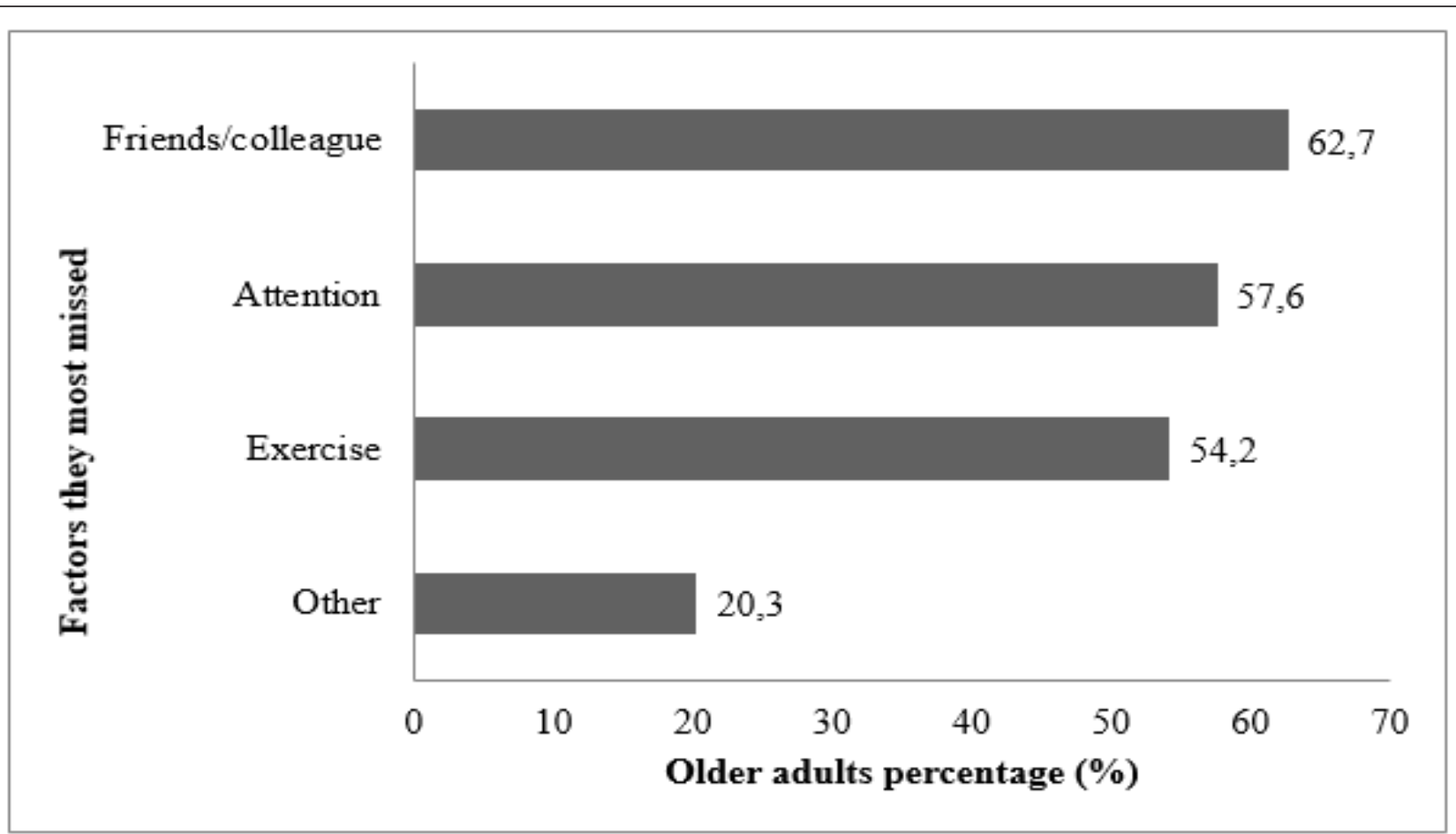

Figure 3 - Factors that older adults missed after abandoning the program.

With regard to the benefits of physical exercise during the period that older adults participated in the program, the participants reported improved health (69.5\%), general well-being (52.5\%), self-esteem (52.5\%), and selfconfidence $(32.2 \%)$ as the most important factors (Figure 4).

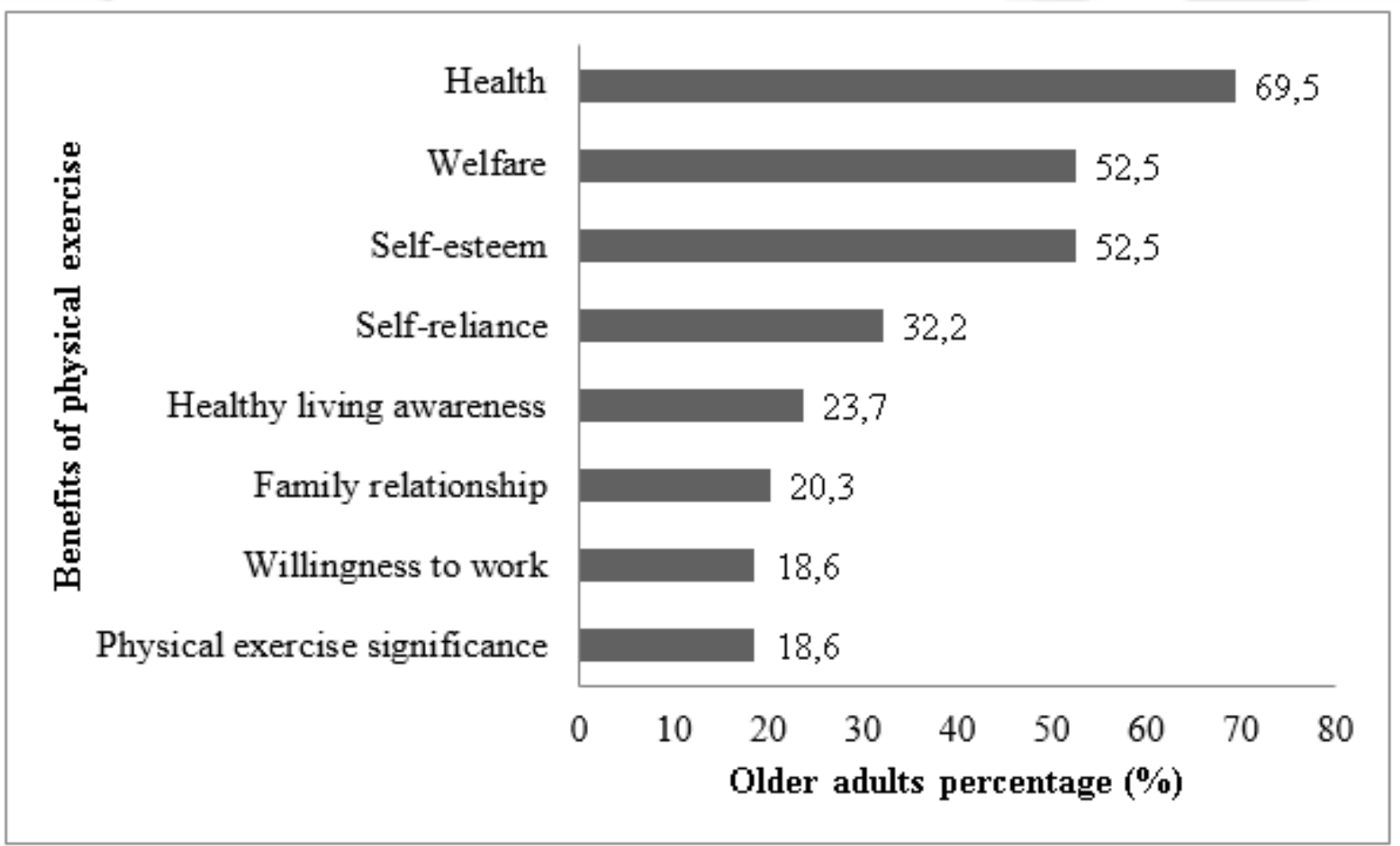

Figure 4 - Benefits of practicing physical exercise during participation in the program. 


\section{Discussion}

Regular practice of physical exercise is fundamental for the maintenance of health, functional independence, and quality of life in old age; however, the dropout rates of programs offering this type of activity are high. The main reasons for abandonment of the older adults in the present study were lack of time, emergence of diseases, and occurrence of illness in relatives. The present data are similar to other studies that also evaluated this construct [7, 25, 26, 28]. However, reports of pain, fatigue, and inadequate exercise, which are usually also cited as reasons for dropout [7, 28], were rarely reported in the present study. One reason for this result is the fact that the program is specifically aimed at older adults, with exercises adjusted to the limitations and abilities of this population, and supervisors are always present in the sessions.

The present study found that older adults who remained with Revita for more than 12 months presented a 5.6 times greater chance of continuing to perform physical exercises even after they gave up the program, when compared to those who remained in the program for a shorter period. It should be noted that these results indicate the importance of structured physical exercise programs for older adults, as they have an important role in creating the habit of practicing exercises. In view of this, approximately $70 \%$ of the older adults in the present study reported maintaining physical exercise after dropping out of the program. A similar result was observed by Caromano, Ide and Kerbauy [4], who evaluated continuity in the elderly who participated in a program for 16 weeks. The authors found that $60 \%$ of the older adults continued in physical exercises after the program ended.

As shown, awareness by the older adults of the benefits of an active life, as well as the perception of health improvement, and feelings of well-being and selfesteem generated during their physical exercise, result in a change in sedentary habits. Devereux-Fitzgerald et al. [32] point out that adherence to practice depends on the assimilation of importance for health, as well as the perception of pleasure that exercise and socialization promote. The perception of pleasure is a motivating factor distinct from the importance for health, as it is seen as a motivating factor for both engagement in and maintenance of exercise practice. In addition, professionals who promote the practice have a direct impact on the experience of the older adults regarding the need to perform and maintain physical exercises
[32]. The result of this set of factors is that the older adults are more likely to initiate and adhere to physical exercise programs [33].

Although the majority of the older adults reported maintaining exercise after withdrawal from Revita, $62.5 \%$ described a worsening in general health and loss of muscle strength, balance, and flexibility. These data point to a possible limitation in the type of exercise performed, and its intensity and frequency. According to the Brazilian Institute of Geography and Statistics [34], the perception of a poor state of health generates an increase in the use of health services; this aspect is currently more often reported by men and is inversely proportional to the average monthly family income per capita. Therefore, the importance of always practicing exercises with the supervision of trained professionals is emphasized.

Among the older adults who reported not performing physical exercise after leaving the program, $77.8 \%$ intended to resume the practice. However, perceived barriers to return were lack of company, lack of willingness and, again, lack of time. These data are in agreement with the studies of Forkan et al. [35], Lee et al. [36], and Groot and Fagerström [37], who also pointed out these aspects as barriers to a possible return to physical exercise.

The reasons for abandoning Revita identified in the present study, such as the appearance or aggravation of diseases of the elderly and the sickness of relatives, have also been frequently pointed out in other studies $[28,35-37]$ as barriers to beginning practice and nonadherence to exercise programs. Thus, the importance of monitoring the health status of the elderly and provision of social support to their sick relatives is emphasized. This makes it possible for the older adult to return to physical exercises as soon as they are able to perform them, reducing major health problems, as previously mentioned.

Another aspect identified in this study was the importance of social contact. This is because, when questioned about which aspect of the program they missed the most, the elderly emphasized the interaction with colleagues $(62.7 \%)$ and attention received by teachers (57.6\%). Cardoso et al. [28] observed that one of the main reasons for joining a physical exercise program was an invitation from friends and/or family members. Manzano and Molina [38] verified that elderly individuals enrolled in a program of physical exercises were motivated mainly by social interaction. Therefore, it is important that physical exercise programs for older adults be carried out in groups that favor the 
conviviality of the participants, since this seems to be an important factor for the adherence and maintenance of participants in these programs $[6,13]$.

It is essential that all health professionals become more involved in prescribing and promoting physical exercise, in addition to educating the elderly about the importance and value of continuity in carrying them out. Moreover, health professionals need to guide older adults with regard to modifying exercise programs when there is a change in health status. When necessary, individualized care should be provided until the older adults return to their previous health condition in order to re-attend group exercise programs. It should be emphasized that it is essential to motivate the older adults to participate in physical exercise groups, in addition to reducing the risk of injury, as a result of the professional guidance, group exercises have proven beneficial to increase social contact.

We can cite the telephone contact as a possible limitation of this study, since it involved a large number of non-localized individuals. However, it should be noted that the interviewer had no previous link with the evaluated older adults.

\section{Conclusion}

The main reasons for the older adults to abandon physical exercise were lack of time, emergence of diseases, and occurrence of illness in relatives. Despite this, the older adults indicated that physical exercise brings benefits to health, well-being, and self-esteem. An alternative to the lack of time pointed out by the older adults would be organization of diaries together with their relatives, since many of them are responsible for the care of family members which restricts their participation in exercise programs. In addition, when the older adults become ill, organization of a network of health care for assistance is fundamental and, once recovered, it is essential to reintegrate the individuals in exercise programs. With regard to sickness of partners and relatives, it is also of great importance that there is organization and support from other members of the family and the health unit, thus enabling their participation in physical exercises.

\section{Acknowledgments}

We are grateful for Educational Foundation São Carlos (FESC) and the financial support granted by the Pro-Rector of Extension (PROEX) of UFSCar, process number 23112.003865/2012-16.

\section{References}

1. Batista MPP, Almeida MHM, Lancman S. Políticas públicas para a população idosa: uma revisão com ênfase nas ações de saúde. Rev. Ter. Ocup. Univ. São Paulo. 2011;22(3):200-207.

2. Instituto Brasileiro de Geografia e Estatística - IBGE, Coordenação de População e Indicadores Sociais. Síntese de indicadores sociais: uma análise das condições de vida da população brasileira. Rio de Janeiro, RJ; 2016.

3. United Nations, Department of Economic and Social Affairs, Population Division. World population prospects: the 2017 revision, key findings and advance tables. New York: Working Paper No. ESA/P/ WP/248; 2017.

4. Caromano FA, Ide MR, Kerbauy RR. Manutenção na prática de exercícios físicos por idosos. Rev. Dep. Psicol., UFF. 2006;18(2):177-192.

5. Gonçalves MP, Alchieri JC. Motivação à prática de atividades físicas: um estudo com praticantes nãoatletas. Psico-USF. 2010;15(1):125-134.

6. Hardy S, Grogan S. Preventing disability through exercise: investigating older adults' influences and motivations to engage in physical activity. J Health Psychol. 2009;14(7):1036-1046.

7. Nascimento MC, Silva OMP, Saggioratto CML, Vargas KCB, Schopf K, Klunk J. O desafio da adesão aos exercícios físicos em grupos de idosos em Palmitos/SC: Motivos para a prática e para a desistência. Rev. Bras. Ativ. Fís. Saúde. 2010;15(3):140-144.

8. Quinn TJ, McArthur K, Ellis G, Stott DJ. Functional assessment in older people. BMJ. 2011;(22)343:d4681. 
9. Giné-Garriga $\mathrm{M}$, Roqué-Fíguls $\mathrm{M}$, Coll-Planas L, SitjàRabert M, Salvà A. Physical exercise interventions for improving performance-based measures of physical function in community-dwelling, frail older adults: a systematic review and meta-analysis. Arch Phys Med Rehabil. 2014;95(4):753-769.

10. Wilcox S, King AC. The effects of life events and interpersonal loss on exercise adherence in older adults. J Aging Phys Act. 2004;12(2):117-30.

11. Chodzko-Zajko W, Schwingel A, Park CH. Successful aging: the role of physical activity. Am J Lifestyle Med. 2009;3(1):20-28.

12. Hernandes NA, Probst VS, Silva Jr RA, Januário RSB, Pitta F, Teixeira DC. Physical activity in daily life in physically independent elderly participating in community-based exercise program. Braz J Phys Ther. 2013;17(1):57-63.

13. Meurer ST. Motivos para a prática de atividades físicas de idosos: uma revisão sistemática dos instrumentos para mensurar a motivação. Estud. interdiscip. envelhec. 2008;13(2):191-203.

14. Santos JLF, Lebrão ML, Duarte YAO, Lima FD. Functional performance of the elderly in instrumental activities of daily living: an analysis in the municipality of São Paulo, Brazil. Cad Saude Publica. 2008; 24(4):879-886.

15. Matsudo SM. Avaliação do idoso: física e funcional. Londrina, PR: Midiograf; 2000.

16. Takahashi ACM, Carnaz L, Farche ACS, Rossi PG, AilyJB. Motivation, adherence and dropout of physical exercise in older adults. In: Ferraresi C. (Org.) Physical exercises: an important tool for physical therapy. New York: Nova Science Publishers; 2015.

17. Tarazona-Santabalbina FJ, Gómez-Cabrera MC, PérezRos P, Martínez-Arnau FM, Cabo H, Tsaparas K, et al. A multicomponent exercise intervention that reverses frailty and improves cognition, emotion, and social networking in the community-dwelling frail elderly: a randomized clinical trial. J Am Med Dir Assoc. 2016; 17(5):426-433.

18. Merquiades JH, Agra JHM, Albuquerque KMD, Costa RC, Navarro AC. A importância do exercício físico para a qualidade de vida dos idosos. Revista Brasileira de Prescrição e Fisiologia do Exercício. 2009; 3(18):597-614.
19. Meurer ST, Benedetti TRB, Mazo GZ. Teoria da autodeterminação: compreensão dos fatores motivacionais e autoestima de idosos praticantes de exercícios físicos. Rev. Bras. Ativ. Fís. Saúde. 2011;16(1):18-24.

20. Arnardottir NY, Koster A, Van Domelen DR, Brychta RJ, Caserotti P, Eiriksdottir G, et al. Objective measurements of daily physical activity patterns and sedentary behavior in older adults: Age, Gene/Environment SusceptibilityReykjavik Study. Age Ageing. 2013;42(2):222-229.

21. Moschny A, Platen P, Klaaben-Mielke R, Trampisch U, Hinrichs T. Barriers to physical activity in older adults in Germany: a cross-sectional study. Int J Behav Nutr Phys Act. 2011;8:121.

22. Matsudo SM, Matsudo VKR, Turíbio LBN. Efeitos benéficos da atividade física na aptidão física e saúde mental durante o processo de envelhecimento. Rev. Bras. Ativ. Fís. Saúde. 2000;5(2):60-76.

23. Brasil. Ministério da Saúde. Secretaria de Vigilância em Saúde. Secretaria de Gestão Estratégica e Participativa. Vigitel Brasil 2006: vigilância de fatores de risco e proteção para doenças crônicas por inquérito telefônico. Brasília, DF; 2007.

24. Brasil. Ministério da Saúde. Secretaria de Vigilância em Saúde. Vigitel Brasil 2016: vigilância de fatores de risco e proteção para doenças crônicas por inquérito telefônico. Brasília, DF; 2017.

25. Ribeiro LB, Zacaroni LM, Rogatto GP, Valim-Rogatto PC. Tempo de adesão, motivos de desistência e perspectivas de retorno de idosos ex-participantes de um programa de atividades físicas. Coleção Pesquisa em Educação Física. 2010;9(4):225-230.

26. Aily JB, Carnaz L, Farche ACS, Takahashi ACM. Perception of barriers to physical exercise in women population over 60. Motriz: Rev. Educ. Fís. 2017;23(2):e101653.

27. Gillette DB, Petrescu-Prahova M, Herting JR, Belza B. A pilot study of determinants of ongoing participation in EnhanceFitness: a community-based group exercise program for older adults. J Geriatr Phys Ther. 2015;38(4):194-201.

28. Cardoso AS, Borges LJ, Mazo GZ, Benedetti TB, Kuhnen AP. Fatores influentes na desistência de idosos em um programa de exercício físico. Movimento (Porto Alegre). 2008;14(1):225-239. 
29. Booth ML, Bauman A, Owen N. Perceived barriers to physical activity among older Australians. J Aging Phys Act. 2002;10:271-280.

30. Franco MR, Tong A, Howard K, Sherrington C, Ferreira $\mathrm{PH}$, Pinto RZ, et al. Older people's perspectives on participation in physical activity: a systematic review and thematic synthesis of qualitative literature. Br J Sports Med. 2015;49(19):1221-1222.

31. Chodzko-Zajko W, David N, Singh MAF, Minson CT, Nigg CR, Salem GJ, et al. Exercise and physical activity for older adults. Med Sci Sports Exerc. 2009;41(7):1510-1530.

32. Devereux-Fitzgerald A, Powell R, Dewhurst A, French DP. The acceptability of physical activity interventions to older adults: a systematic review and meta-synthesis. Soc Sci Med. 2016;158:14-23.

33. Pavey T, Taylor A, Hillsdon M, Fox K, Campbell J, Foster $\mathrm{C}$, et al. Levels and predictors of exercise referral scheme uptake and adherence: a systematic review. J Epidemiol Community Health. 2012; 66(8):737-44.

34. Instituto Brasileiro de Geografia e Estatística - IBGE. Indicadores Sociodemográficos e de Saúde no Brasil. Rio de Janeiro, RJ; 2009.
35. Forkan R, Pumper B, Smyth N, Wirkkala H, Ciol MA, Shumway-Cook A. Exercise adherence following physical therapy intervention in older adults with impaired balance. Phys Ther. 2006; 86(3):401-410.

36. Lee C, Ory MG, Yoon J, Forjouh SN. Neighborhood walking among overweight and obese adults: age variations in barriers and motivators. J Community Health. 2013;38(1):12-22.

37. De Groot GCL, Fagerström L. Older adult's motivating factors and barriers to exercise to prevent falls. Scand J Occup Ther. 2011;18(2):153-160.

38. Manzano AB, Molina SF. Motivos de inscripción, permanencia y satisfacción en un programa de actividad física de manteniniento para mujeres mayores. CPD. 2012;12(1):79-92.
Received in $06 / 28 / 2017$

Recebido em 28/06/2017

Recibido en 28/06/2017

Approved in 05/29/2018 Aprovado em 29/05/2018 Aprobado en 29/05/2018 